\title{
F18-FDG PET/CT in retroperitoneal desmoplastic small round blue cell tumour occurring in a patient with in situ breast carcinoma
}

\author{
Doina Piciu, ${ }^{1}$ Elena Barbus, ${ }^{2}$ Claudiu Pestean, ${ }^{2}$ Andra Piciu ${ }^{3}$
}

${ }^{1}$ Iuliu Hatieganu University of Medicine and Pharmacy, Cluj-Napoca, Romania ${ }^{2}$ Department of Nuclear Medicine, Institute of Oncology "Prof Dr I Chiricuta", Cluj-Napoca, Romania ${ }^{3}$ Department of Oncology, Institute of Oncology "Prof Dr I Chiricuta", Cluj-Napoca, Romania

\section{Correspondence to} Dr Doina Piciu, doina.piciu@gmail.com

Accepted 9 September 2015
CrossMark

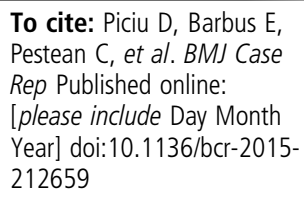

\section{DESCRIPTION}

We present a case of a 58-year-old woman, diagnosed with low-grade in situ ductal breast carcinoma $(3 \mathrm{~mm})$, who underwent conservative mastectomy. She was admitted 7 months later for diffuse abdominal and bone pain, weight loss, and an enlargement of the abdomen, asthenia, cough

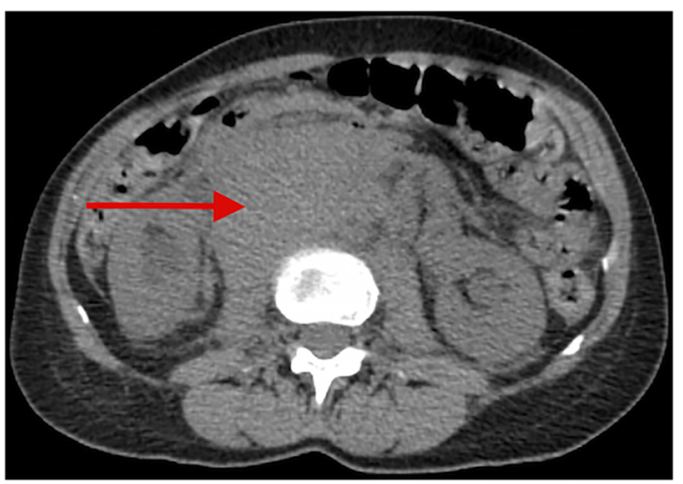

Figure 1 Axial abdominal CT section, presenting pathological para-aortic tumour mass. and nausea. Breast imaging and specific clinical examinations were negative for recurrence of malignant breast disease, but chest and abdominal CT revealed multiple tumour masses in the mediastinum, and multiple lytic lesions in the sternum, ribs, right humerus and pathological para-aortic lymph nodes (figure 1).

The common tumour markers for breast, ovaries, lung, colon, pancreas and neuroendocrine tumours were normal and, apart from a mild anaemia, no other significant serological changes were found.

The clinician requested an F18-fludeoxyglucose positron emission tomography (FDG PET)/CT examination in order to define the extent of the disease and to find the primary site. The result showed a very high and extensive FDG uptake in the retroperitoneal area due to a $27 \mathrm{~cm}$ tumour involving both ureters, with secondary obstruction (figure 2A); there was also high pathological FDG activity in the bilateral cervical lymph nodes, mediastinum and inguinal lymph nodes; there were multiple bone lesions in the right humerus, sternum, ribs, pelvic bones and left femur (figure 2B). The diagnosis was possible metachronous lymphoma or

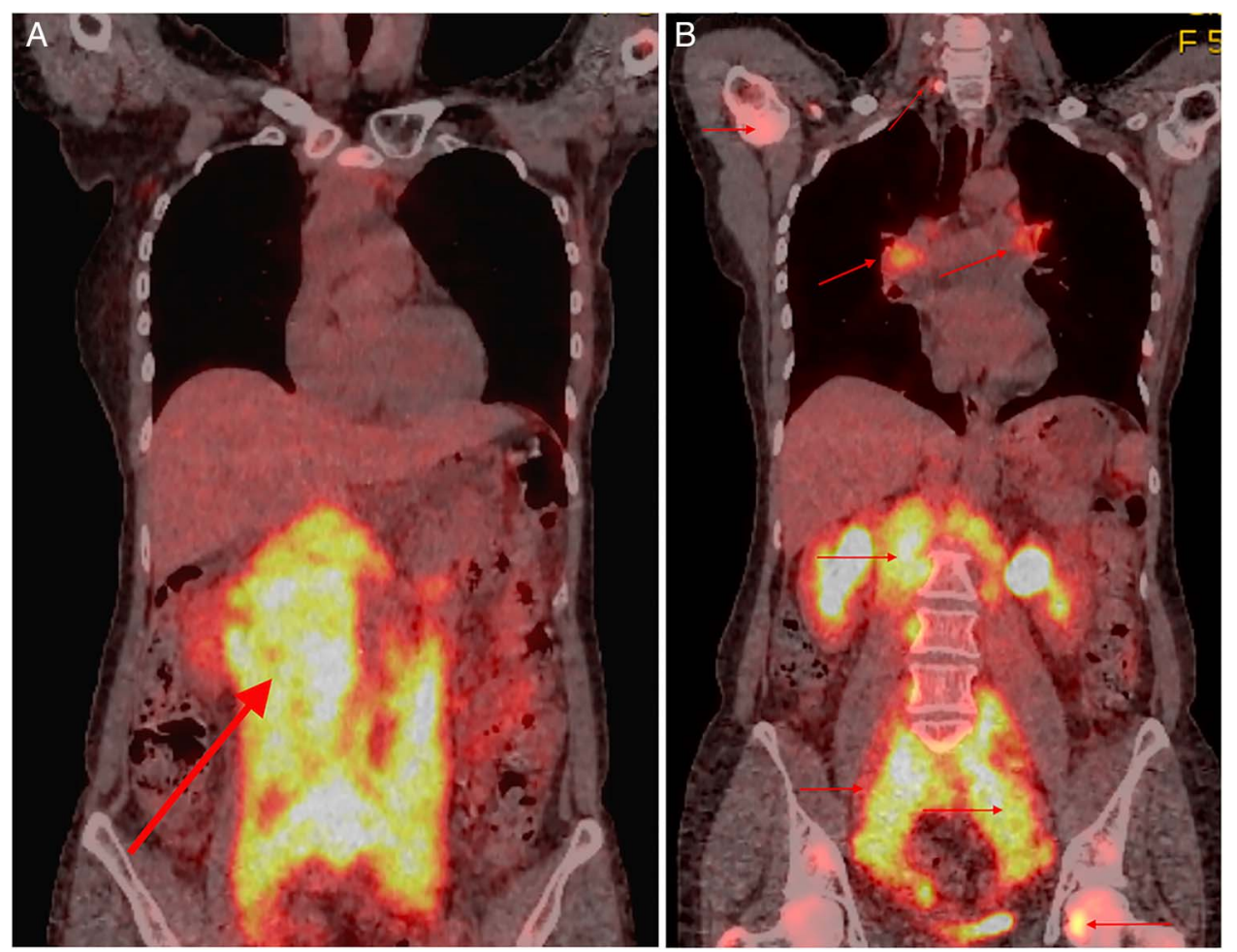

Figure 2 Whole-body F18-fludeoxyglucose positron emission tomography (FDG PET)/CT coronal section, presenting pathological high uptake (A) in a massive retroperitoneal tumour mass and (B) in cervical and mediastinum lymph nodes, and in the retroperitoneal mass, and lytic lesions in right humerus and left femur. 


\section{Learning points}

- Multiple malignant pathologies should not be missed in a patient with cancer.

- F18-fludeoxyglucose positron emission tomography (FDG $\mathrm{PET} / \mathrm{CT}$ is not routinely indicated in the evaluation of the early stages of breast carcinoma, but should be used anytime during follow-up, if the clinical situation requires it.

- Desmoplastic small round cell tumour is a rare sarcoma with aggressive evolution, presenting high F18-FDG uptake at PET/CT.

sarcoma. ${ }^{1}$ Surgical biopsy of the retroperitoneal mass and inguinal lymph nodes was indicated. The histology of both specimens was desmoplastic small round cell tumour. This is a rare sarcoma characterised by poorly differentiated small round blue cells and abundant fibrosclerotic stroma. ${ }^{2}$

Contributors DP was responsible for imaging evaluation and design of the case; $\mathrm{EB}$ and $\mathrm{CP}$ performed the imaging examinations and revised the manuscript; and $\mathrm{AP}$ revised the manuscript.

Competing interests None declared.

Patient consent Obtained.

Provenance and peer review Not commissioned; externally peer reviewed.

\section{REFERENCES}

1 Hong SP, Lee SE, Choi YL, et al. Prognostic value of 18F-FDG PET/CT in patients with soft tissue sarcoma: comparisons between metabolic parameters. Skeletal Radiol 2014:43:641-8.

2 Chang F. Desmoplastic small round cell tumors: cytologic, histologic, and immunohistochemical features. Arch Pathol Lab Med 2006;130:728-32.

Copyright 2015 BMJ Publishing Group. All rights reserved. For permission to reuse any of this content visit

http://group.bmj.com/group/rights-licensing/permissions.

BMJ Case Report Fellows may re-use this article for personal use and teaching without any further permission.

Become a Fellow of BMJ Case Reports today and you can:

- Submit as many cases as you like

- Enjoy fast sympathetic peer review and rapid publication of accepted articles

- Access all the published articles

- Re-use any of the published material for personal use and teaching without further permission

For information on Institutional Fellowships contact consortiasales@bmjgroup.com

Visit casereports.bmj.com for more articles like this and to become a Fellow 